\title{
EMPLOYEE REPUDIATION OF BARGAINING REPRESENTATIVES: AN APPRAISAL OF EXISTING RESTRICTIONS
}

Section seven of the National Labor Relations Act guarantees employees the right to choose their own bargaining representative. ${ }^{1}$ This right is exercisable by majority vote, ${ }^{2}$ ascertained either by informal count ${ }^{3}$ or in an election conducted by the National Labor Relations Board. 4 If a majority of employees chooses a union, the union will be the exclusive representative for all employees, with power to negotiate a contract binding on all..$^{5}$ If a majority is opposed to unionism or cannot agree upon a particular union, the employees may deal individually with their employer. ${ }^{6}$

1. "Employees shall have the right to self-organization, to form, join, or assist labor organizations, to bargain collectively through representatives of their own choosing, ... and shall also have the right to refrain from any or all of such activities. ..."

49 Stat. 452 (1935), as amended, 29 U.S.C. § 157 (1952).

2. 49 Stat. 453 (1935), as amended, 29 U.S.C. $\$ 159$ (a) (1952). The voting unit is the "appropriate bargaining unit," which may be defined on a single craft, plant, employer or multiple-employer basis. Cox, LABOR LAw 325-34 (3d ed. 1954). Initial power to determine which unit is appropriate for bargaining, and hence for elections, is vested in the National Labor Relations Board, but its determination may be judicially reviewed in proceedings before a United States Circuit Court of Appeals to enforce an order to bargain. Pittsburgh Plate Glass Co. v. NLRB, 313 U.S. 146, 154 (1941) ; Jones \& Laughlin Steel Corp. v. NLRB, 146 F.2d 833 (5th Cir.), cert. denied, 325 U.S. S86 (1945).

3. NLRB v. Valley Broadcasting Co., 189 F.2d 582, 586 (6th Cir. 1951) (count of union application cards) ; NLRB v. Somerset Shoe Co., 111 F.2d 681, 687 (1st Cir. 1940) (same); 2 Teller, Labor Disputes and Collective Bargaining $\S 326$, at $872-73$ (1940). An employer acts at his peril in refusing to recognize a union that claims to have been selected by a majority of employees of an appropriate bargaining unit, even though no determination or designation has been made by the Board. The refusal to recognize is an unfair labor practice unless the employer can show that in the exercise of reasonable judgment he lacked knowledge of the appropriateness of the unit or of the selection by a majority of his employees. NLRB v. Piqua Munising Wood Products Co., 109 F.2d 552, 556 (6th Cir. 1940).

4. A petition for election may be filed pursuant to $\S 9$ (c) (1) by employer, employees or union. If presented by union or employees, it must allege that the employees wish to be represented and the employer refuses to recognize their choice, or that the currently recognized or certified union has lost majority support. If filed by the employer, the petition must allege that the employer is beset with conflicting claims to recognition. The Board investigates each petition and, upon a finding that a question of representation affecting interstate commerce exists, directs an election by secret ballot. 49 STAT. 452 (1935), as amended, 29 U.S.C. \& 159(c) (1) (1952); 29 C.F.R. $\$ \$ 102.52-102.66$ (Supp. 1955) (procedural rules for elections).

5. 49 Stat. 453 (1935), as amended, 29 U.S.C. $\$ 159$ (a) (1952); Medo Photo Supply Corp. v. NLRB, 321 U.S. 678, 683-85 (1944); J. I. Case Co. v. NLRB, 321 U.S. 332 (1944); Adams v. Republic Steel Corp., 254 Ala. 620, 625, 49 So. 2d 214, 218 (1950).

6. It is an unfair labor practice for an employer to treat a union selected by only a minority of employees as exclusive bargaining representative for all employees. E.g., 
Protection of the right to a bargaining arrangement of one's own choosing, however, is not the principal policy of the National Labor Relations Act. The act expressly states that industrial harmony is its major goal; freedom of choice is guaranteed because it is conducive to that end. ${ }^{7}$ The history of industrial relations demonstrated that refusals of employers to recognize independent unions and the often concomitant insistence on company-dominated unions were major causes of strikes. ${ }^{8}$ The guarantee of free choice of bargaining representation was intended as an antidote to these evils. ${ }^{9}$

Frequent change of unions, however, may defeat industrial harmony by preventing an employer from reaching or maintaining a working agreement with his employees. Therefore, although the act as originally passed contained no express limitation on employees' freedom of choice, the Board has sought to keep means subordinated to ends by limiting employees' right to repudiate a bargaining representative selected by them. Two rules, known as the certification year and contract bar rules, embody these limitations. In 1947 Congress adopted an additional, and in many respects overlapping, restriction on free choice: the election year rule. ${ }^{10}$

Although these limitations subserve the immediate objective of stabilizing union representation, this Comment will question their contribution to the ultimate goal of industrial harmony. First the Comment will describe the operation of the rules. Next it will show that not all applications of the rules can be justified in terms of industrial stability. The Comment will conclude that logic

NLRB v. Henry Heide, Inc., 219 F.2d 46 (2d Cir. 1955) ; Long-Lewis Hardware Co., 90 N.L.R.B. 1403, 1416 (1950); Blossom Products Corp., 20 N.L.R.B. 335, 348-49 (1940). However, such a union may serve as bargaining agent for its members. NLRB v. Reliable Newspaper Delivery, Inc., 187 F.2d 547 (3d Cir. 1951) ; Hoover Co., 90 N.L.R.B. 1614, 1618 (1950).

7. Section 1 outlines congressional findings that denial by employers of the right to organize has led to strikes and industrial unrest, and declares that the policy of the United States is to eliminate such causes by "protecting the exercise by workers of full freedom of association, self-organization, and designation of representatives of their own choosing." 49 Stat. $449-50$ (1935), as amended, 29 U.S.C. $\$ 151$ (1952). Section 7 guarantees the right of free choice. See note 1 supra.

8. Bow, Independent Labor Organizations and the National Labor Rerations Acr 2-3 (1940). Senator Wagner, the author of the act, stated:

"Again and again they [investigating commissions] found that the denial of labor's right to be heard in the councils of industry was the root cause of the industrial struggle. Again and again, they found that the recognition of this right was the only sure basis for industrial peace and the rational conduct of business affairs."

Hearings before the Senate Committee on Education and Labor, 76th Cong., 1st Sess., pt. 1, at 5 (1939). These sentiments are embodied in $\$ 1$ of the act. See note 7 supra.

9. See notes 7,8 supra. The guarantee is implemented in $\S 8$ (a) (5), making it an unfair labor practice for an employer to refuse to bargain with the majority-designated union. 49 STAT. 453 (1935), as amended, 29 U.S.C. \$ 158(a) (5) (1952).

10. 61 Stat. 144 (1947), 29 U.S.C. $\$ 159$ (c) (3) (1952), amending 49 Stat. 453 (1935). See note 17 infra and accompanying text. 
should lead to some relaxation of the rules; empirical study by the Board might result in further loosening.

\section{The Certification and Election Year Rules}

The certification year rule immunizes a union elected as a bargaining agent from rapid repudiation. The rule bars all elections for one year from the date a union is certified as winner of an election conducted by the Board or other impartial body. ${ }^{11}$ Moreover, during the year informal balloting cannot be used to challenge the union's right to act as exclusive bargaining agent. Thus the Supreme Court has held that an employer committed an unfair labor practice by not bargaining with a certified union, even though seventy percent of his employees had informed him that they had repudiated the union as their bargaining agent. ${ }^{12}$

Before 1947 the certification year rule did admit of certain exceptions, allowing repudiation of a union under unusual circumstances. The Board would hold elections if one of the following conditions were met: the bargaining unit had changed significantly through the addition or reduction of crafts or workers $;^{\mathbf{1 3}}$ the certified union was defunct $;^{14}$ a schism had occurred in the certified

11. Olin Mathieson Chemical Corp., LAB. ReL. ReP. (38 L.R.R.M. 1099) (NLRB June 6, 1956) (election supervised by state labor board) ; Rockwell Valves, Inc., LAB. ReL. REP. (37 L.R.R.M. 1271) (NLRB Jan. 27, 1956) ; Centr-O-Cast \& Engineering Co., 100 N.L.R.B. 1507 (1952). The Supreme Court approved the rule in Brooks v. NLRB, 348 U.S. 96 (1954). Certification consists of a statement by the Board that a union was elected bargaining representative.

The certification year rule was first introduced in 1937, National Sugar Refining Co., 4 N.L.R.B. 276 (1937), and its term was fixed at one year in 1938, Todd-Johnson Dry Dock, Inc., 10 N.L.R.B. 629, 632 (1938). The New York State Labor Relations Board, administering an act patterned after the National Labor Relations Act, has adopted the certification year rule. F. T. Ham Constr. Co., 14 N.Y.S.L.R.B. 83 (1951); New York Labor Board v. L. Morales \& Sons, Inc., 113 N.Y.S.2d 518 (Sup. Ct. 1951). Other states with similar acts have included a certification year rule in their statutes. E.g., MrNn. Stat. Ann. § 179.16(2) (Supp. 1955); PA. Stat. Ann. tit. 43, § 211.7 (c) (Purdon Supp. 1955).

On the doctrinal level the rule has been regarded as creating a conclusive presumption of the continuance of majority support. NLRB v. Globe Atomatic Sprinkler Co., 199 F.2d of (3d Cir. 1952).

12. Brooks v. NLRB, 348 U.S. 96 (1954), 69 HARv. L. Rev. (1955). The Court reasoned that the Board must have the power to make its certification year rule effective against employers as well as against employees. Otherwise the employer would be allowed to assert the rights of his employees at a time when they could not directly assert those rights themselves under the certification year rule. Brooks overruled a number of appellate court decisions holding that the employer could question the authority of a certified union during the certification year. Mid-Continent Petroleum Corp. v. NLRB, 204 F.2d 613 (oth Cir.), cort. denied, 346 U.S. 856 (1953) ; NLRB v. Vulcan Forging Co., 188 F.2d 927 (6th Cir. 1951).

13. Aluminum Co. of America, 51 N.L.R.B. 1295 (1943) ; Electric Sprayit Co., 67 N.L.R.B. 7\&0 (1946). Generally a mere increase or decrease in the number employed is not sufficient to bring the exception into play. There must be other changes as well, such as a material change in processes or operations. Electric Sprayit Co., supra. 
union and each of two factions claimed to be the exclusive elected representative of the workers. ${ }^{15}$ In each of these situations the certified union was considered unlikely to be able to negotiate a rational collective bargaining agreement. Hence giving the certified union security would contribute nought to industrial stability. ${ }^{18}$

Most of the significance of the policy-oriented exceptions to the certification year rule was erased in 1947 by the enactment of the election year rule. ${ }^{17}$ This rule absolutely prohibits the Board from holding more than one election every twelve months. What meaning the exceptions now have is solely attributable to the fact that the certification year and election year are not coterminous. The certification year begins only after all disputes over the way an election has been conducted are settled, ${ }^{18}$ while the election year runs from the date of

The changing character of a unit is also relevant in determining whether to hold the first election. Confronted with the desiderata of giving employees immediate representation and certifying a union that can satisfy the workers' needs, the Board has at various times experimented with three different approaches: (1) not holding an election if a more representative one can be held within a short time, Harnischfeger Corp., 66 N.L.R.B. 252 (1946) ; (2) holding a Westinghonse election: union is certified but new election may be held within certification year, Westinghouse Elec. Co., 38 N.L.R.B. 404 (1942); (3) holding a regular election if the unit is fairly representative, Aluminum Co. of America, supra. The Board can no longer hold a Westinghouse election; where such an election would have been held, the Board now directs an immediate election. Western Elec. Co., 76 N.L.R.B. 400 (1948).

14. Public Serv. Elec. \& Gas Co., 59 N.L.R.B. 325 (1944). Unions rarely dissolve during the certification year. As a result the defunct union exception has been applied mainly to avoid the contract bar rule, and it is in these cases that the term "defunct" has been given its definition. See note 47 infra.

15. Jasper Wood Products Co., 72 N.L.R.B. 1306 (1947) ; Carson Pirie Scott Co., 69 N.I.R.B. 935 (1946) ; Brightwater Paper Co., 54 N.L.R.B. 1102 (1944). For discussion of the history and meaning of the exception, see notes 49-55 infra and accompanying text.

16. Changed unit exception: Any significant change, through the addition or reduction of crafts or through a substantial increase or decrease in the working force, was thought to make the certified union unrepresentative and hence unable to negotiate a contract satisfactory to all. See Electric Sprayit Co., 67 N.L.R.B. 780 (1946).

Defunct union exception: Denying an election after the certified union had become defunct would cause instability because there would be no union to represent the workers' interest and negotiate a collective agreement. See Public Serv. Elec \& Gas Co., 59 N.L.R.B. 325 (1944).

Schism exception: A schism creates a doubt as to the identity of the union chosen by the employees. Until that doubt is resolved industrial relations remain at a standstill. See Carson Pirie Scott Co., 69 N.L.R.B. 935 (1946).

17. Section 9 (c) (3) provides: "No election shall be directed in any bargaining unit or any subdivision within which in the preceding twelve-month period, a valid election shall have been held." 61 STAx. 144 (1947), 29 U.S.C. \$ 159 (c)(3) (1952), amending 49 STAт. 453 (1935). Where the original election fails to produce a majority for either a union or individual bargaining, and at least two unions were on the ballot, one run-off election may be held. 29 C.F.R. $\$ 102.62$ (Supp. 1955).

18. Id. $\$ 102.61$. See Brooks v. NLRB, 348 U.S. 96, 104 (1954). See also note 11 supra. 
balloting. ${ }^{10}$ Therefore the only opportunity for applying an exception comes when an election is demanded after the expiration of the election year but before the end of the certification year. ${ }^{20}$ This period ranges from one week to six months or more. ${ }^{21}$

Neither the certification nor the election year rules forestall the repudiation of bargaining representatives who have been selected informally. ${ }^{22}$ Both rules bar change only after selection has been made through a formal election. The freedom of choice this limitation appears to preserve is illusory, however. Any union that fears loss of employee support in the ensuing year may, and undoubtedly will, seek an election from the Board. And the Board will hold elections even though the only reason is to give the union the protection of the certification year rule. ${ }^{23}$

\section{Contract Bar Rule}

The certification and election year rules afford a union at least one year of security. The union may extend this period by executing a collective bargaining agreement. That event brings into play the contract bar rule, preventing any change in representation during the life of a contract of reasonable duration, ${ }^{24}$ or, if the contract is deemed to be of inordinate length, for a reason-

19. Palmer Mfg. Co., 103 N.L.R.B. 336 (1953); Fruitvale Canning Co., 85 N.L.R.B. 684 (1949).

20. This opportunity presented itself in Aleo Mfg. Co., 109 N.L.R.B. 1297, 1302 n.18 (1954) (election denied because the requisites of the schism exception were not met) and Swift \& Co., 94 N.L.R.B. 917 (1951) (election directed because of the existence of a valid schism).

21. For examples of certifications issued within the week after an election, see NLRB Press Release, No. W-473, Oct. 17, 1956, pp. 9-10. For examples of certifications issued over six months after an election, see Colgate-Palmolive-Peet Co., 102 N.L.R.B. 1405 (1953); Kennecott Copper Corp., 102 N.L.R.B. 1391 (1953).

22. NLRB v. Raeder Motor Co., 202 F.2d 802 (6th Cir. 1953) (union designated by show of membership cards repudiated shortly afterward); NLRB v. Mayer, 196 F.2d 286 (5th Cir. 1952) (same).

23. General Box Co., 82 N.L.R.B. 678 (1949). The petitioning union must show that it has been designated by at least thirty percent of the employees to obtain an election. Usually a membership list is sufficient proof. Cox, LABOR Law 307-08 (3d ed. 1954). See 29 C.F.R. \& 101.17(a) (1949).

24. Kellog \& Sons, Inc., LAB. REl. Rep. (37 L.R.R.M. 1426) (NLRB March 19, 1956); General Motors Corp., 102 N.L.R.B. 1140 (1953); Saginaw Furniture Shops, Inc., 97 N.L.R.B. 1488 (1952).

The rule was adopted in 1938. Superior Elec. Products Co., 6 N.I.R.B. 19 (1938). Earlier the Board had refused to allow a contract to suspend the right of free choice. New England Transp. Co., 1 N.L.R.B. 130, 138-39 (1936): "The whole process of collective bargaining and unrestricted choice of representatives assumes the freedom of the employees to change their representatives, while at the same time continuing the existing agreements under which the representatives must function."

Traditionally, the Board denied the bar rule to contracts signed after a rival union had filed an election petition. The Grace Co., 73 N.L.R.B. 1286 (1947). Recently, however, the Board ruled that a contract executed after a rival union filed an election petition, but before it notified the employer of its claim to representative status is entitled to 
able period. ${ }^{25}$ Unlike the certification and election year rules, the bar of a contract applies whether the contracting union was selected by election or by informal balloting. ${ }^{20}$

The contract bar rule is in a state of growth. Controversies have developed over what is a reasonable length, what constitutes an adequate contract, and what circumstances justify withholding the bar. In each of these areas recent Board decisions indicate a clear policy of increasing the protection aftorded a contracting union.

\section{Period of Bar}

The "reasonable" period of time during which a contract will bar a change of union has steadily been expanded. Before 1947 a contract could generally bar an election for only one year. ${ }^{27}$ In this experimental era of labor relations, contracts of greater length were thought to be incapable of providing stability. ${ }^{24}$ In 1947, however, two years became the ordinary period. ${ }^{29}$ Experience had demonstrated that two-year contracts could stabilize relations, if the negotiating union was left in charge of the grievance procedure. ${ }^{30}$ In 1953 the Board further extended the period by ruling that five-year contracts, when adopted by a substantial portion of an industry, would bar any change for their full duration. 31

the protection of the bar. Anheuser-Busch, Inc., LAB. REL. REP. (38 L.R.R.M. 1193) (NLRB July 23, 1956).

New York also has the contract bar rule. Suffridge v. O'Grady, St N.Y.S.2d 211 (Sur. Ct. 1948). Pennsylvania has a hybrid form. A new union may be certified during the life of an existing contract for the sole purpose of negotiating a contract which will take effect upon the expiration of the old agreement. The repudiated union will remain in charge of the old agreement. P.R.T. Employees Union v. Pennsylvania Labor Relations Board, 51 Pa. D. \& C. 47 (C.P. 1943).

25. Supreme Sunrise Food Exchange, Inc., 105 N.L.R.B. 918 (1953); The Mennen Co., 105 N.L.R.B. 677 (1953) ; San Francisco Retailers Council, 90 N.L.R.B. 1803 (1950).

26. Asplundh Tree Expert Co., 92 N.L.R.B. 1013 (1950); United States Time Corp., 79 N.I.R.B. 1135 (1948),

27. The A. S. Abell Co., 62 N.L.R.B. 1414, 1416 (1945) ; The Trailer Co., 51 N.L.R.B. 1106, 1109 (1943) ; Inland Container Corp., 47 N.L.R.B. 952, 954 (1943). However, contracts of two-year duration were permissible if customary in the industry. OwensIllinois Pac. Coast Co., 36 N.L.R.B. 990 (1941); Inland Container Corp., supra (dictum).

28. In The Trailer Co., 51 N.L.R.B. 1106 (1943), the Board, in permitting an election after one year although the contract was to run for duration of war, stated that denying an election would serve to "aggravate rather than minimize discord and to remove the foundation on which stability can be based." Id. at 1111. In Reed Roller Bit Co., 72 N.L.R.B. 927 (1947), in extending the permissible duration to two years, the Board said that it had permitted elections every year previously because collective bargaining was in a stage of trial and error. Id. at 930.

29. Puritan Ice Co., 74 N.L.R.B. 1311 (1947) ; Reed Roller Bit Co., 72 N.L.R.E. 927 (1947). The Board had begun to relax its requirements in 1945 by holding that two-year contracts would be deemed reasonable unless shown to be contrary to a well established custom in the industry. Uxbridge Worsted Co., 60 N.L.R.B. 1395 (1945).

30. See cases cited note 29 supra.

31. General Motors Corp., 102 N.L.R.B. 1140 (1953) (five-year contract bar permis- 


\section{Types of Contract}

The Board has also enlarged the category of contracts to which the bar will apply. Originally, for the bar to operate a contract had to be legally enforceable and broad enough to cover most conditions of employment. ${ }^{32}$ Recent Board decisions do not insist upon these requirements. If there is evidence of good labor relations generally, the contract will bar a change of union. ${ }^{33}$ Thus the Board in Rohm \& Haas ${ }^{34}$ held that a contract terminable at will barred an election for two years. And in Nash Kelvinator ${ }^{35}$ the Board gave similar effect to a contract providing only for wage rates. Extrinsic evidence in each case convinced the Board of the harmonious relationship between the parties. $^{30}$

sible in the automobile industry); Allis Chalmers Mfg. Co., 111 N.L.R.B. 389 (1955) (same in farm equipment manufacturing industry); Royal Jet, Inc., LAB. REL. REP. (36 L.R.R.M. 1477) (NLRB Aug. 25, 1955) (three-year contract bar permissible in the aircraft industry, but contracting union failed to meet the burden of showing that it was in that industry); Home Curtain Corp., 111 N.L.R.B. 336 (1955) (three year contracts permissible in the curtain industry. For a history and discussion of the Board's treatment of duration problems, see Lahne, The Duration of Labor Agreements and the Contract Bar Doctrine of the N.L.R.B., 5 Syracuse L. Rev. 146 (1954). There is a trend away from the five-year agreement in the automobile industry. Recently Ford and General Motors, after experimenting with five-year contracts, shifted to three-year agreements. See Agrement betz'een General Motors Corp. and UAW-CIO, BNA Collectrve BaRgaining Negotiations aND Contracts 20:301 (1955); Agreement between Ford Motor Co. and UAW-CIO, id. at 20:401.

A substantial portion of an oligopolistic industry is likely to be bound by contracts of equal length because generally a single union represents the employees of all companies and pattern bargaining with the individual companies is customary. See, e.g., Business Week, June 9, 1956, p. 29 (steel industry). Such contracts are also the norm in competitive industries which bargain as a unit with labor. See, e.g., Contract between Merchants' Ladies' Garment Ass'n, Inc. and ILGWU-AFL, BNA Collective Bargalning NEGotIATIONS AND CoNTRACTS $23: 1$ (1955).

32. A contract terminable at will could not bar an election. Mid-Continent Coal Corp., 82 N.L.R.B. 261 (1949) ; Pontosi Tie \& Lumber Co., 73 N.L.R.B. 590 (1947); Iona Desk Co., 59 N.L.R.B. 1522 (1945). Nor could a contract which required further ratification by union members. American Broadcasting Co., LAB. REL. REP. (36 L.R.R.M. 1494) (NLRB Aug. 31, 1955). A contract also had to provide the substantive terms of employment in order to act as a bar. A. O. Smith Corp., 78 N.L.R.B. 1050 (1948) (wage agreement is not sufficient); Standard Oil Co., 56 N.L.R.B. 1101 (1944) (agreeruent not sufficient which only provided for recognition and handling of grievances); Wilmington Terminal Warehouse Co., 68 N.L.R.B. 299 (1946) (by implication). See also Eicor, Inc., 46 N.L.R.B. 1035 (1943) (contract must be reduced to writing).

33. See authorities cited in notes 34,35 infra. See also Phelps Dodge Refining Corp., 112 N.L.R.B. 1209, 1212 (1955): "Furthermore, assuming argnendo that the contract was not ratified in accordance with Intervenor's constitution, the record shows that the contract was nevertheless put into effect and that the formality of ratification was not necessary to stabilize bargaining relations."

34. 108 N.L.R.B. 1285 (1954).

35. 110 N.L.R.B. 447 (1954).

36. In Rohm \& Haas the Board said:

"That the former rule governing contracts terminable at will would have the 
Vestiges of the old view remain, however. Under prior requirements, longterm contracts allowing broad renegotiation at the end of one year or providing for automatic annual renewal unless expressly terminated by a party at the end of each year barred elections for only one year. ${ }^{37}$ Although these contracts are no less binding than contracts terminable at will, the Board still refuses to allow them to bar for longer than a year. ${ }^{38}$ No justification has been advanced for this differential treatment. ${ }^{39}$ Two out of five members of the Board have advocated allowing contracts with broad renegotiation clauses to bar for two years. ${ }^{40}$ A third member appears to be yielding to their logic.41 If contracts with broad renegotiation clauses are held to bar for two or more years, establishment of a similar rule for automatic renewal contracts should follow as a matter of course. ${ }^{42}$

The shift in emphasis from the comprehensiveness and enforceability of a collective bargaining agreement to the stability effected by the collective bar-

effect of disturbing industrial peace is emphasized by this very case. The record shows that the Employer and the Intervenor have enjoyed harmonious industrial relations since the Intervenor was certified as the representative of the Employer's employees more than 5 years ago."

108 N.L.R.B. at 1287. In Nash Kelvinator the Board stressed similar factors. 110 N.L.R.B. at 449 .

37. Central Rufina, 108 N.L.R.B. 307 (1954) (automatic renewal contract); J. C. Hirschman Co., 106 N.L.R.B. 529 (1953) (same) ; Mill B, Inc., 40 N.L.R.B. 346 (1942) (same); General Elec. Co., 108 N.L.R.B. 1290 (1954) (contract with broad renogiation clause).

38. See, e.g., Ketchikan Pulp Co., LAB. Ret. ReP. (37 L.R.R.M. 1287) (NLRB Jan. 31, 1956).

39. Automatic renewal contracts, contracts with broad renegotiation clauses, and terminable-at-will contracts are virtually interchangeable. All allow for revision of the terms of the contract. Terminable contracts differ from the others in that modifications may be discussed at any time. Automatic renewal contracts and contracts with broad renegotiation clauses permit revision only at stated intervals. However, it is an unfair labor practice to terminate any contract, including one terminable at will, without giving the other party sixty-days notice. 61 STar. 142 (1947), 29 U.S.C. \$ 158(d) (1) (1952). From the point of view of healthy labor relations, contracts with broad renegotiation clauses are preferable, because they assure to the employer the continuation of the existing seniority system and grievance procedure and at the same time they preserve the workers' right to seek higher wages. For further discussion of the various types of agreements, see BNA, Collective Bargaining Negotiations and Contracts 36:1-543 (1956).

40. See dissenting opinions of Murdock and Peterson in Ketchikan Pulp Co., LAB. REL. REP. (37 L.R.R.M. 1287, 1290-92) (NLRB Jan. 31, 1956). Since contracts providing for broad renegotiation allow unions to seek periodic wage increases, unions might be willing to enter into them for long terms. If freedom of choice is to remain a basic tenet of labor law, these contracts must not be allowed to bar for their full length.

41. Member Bean concurred in the decision of the Board in Ketchikan Pulp Co., supra note 40 , directing an election. His reasoning, however, was not based on the fact that the contract had a renegotiation clause but on the fact that the union had exercised its right to modify the contract pursuant to the renegotiation clause. Apparently he would advocate a different result if neither party saught modification. Id. at 1289-90.

42. See note 39 supra. 
gaining arrangement is the welcome product of recently acquired knowledge on labor relations. In its infancy the National Labor Relations Board thought that a collective bargaining agreement would, by itself, produce stability, since an aggrieved party could turn to the courts for the enforcement of his contractual rights. ${ }^{43}$ Thus, when a comprehensive contract, enforceable in court, had been executed, no significant function remained for the bargaining representative.44 At best the selection of a new representative was purposeless; at worst it could result in subverting the agreement. Currently, however, labor relations experts recognize that securing industrial peace requires a continuing barter relationship: the collective bargaining agreement is the beginning of the bargaining process, not the end. ${ }^{45}$ So viewed, the proven ability of a union to effect compromise between workers and employer is a more meaningful indicium of industrial peace than the enforceability and completeness of a contract.

43. "Normally, [a collective bargaining agreement] . . . is both means and proof of the achievement of that stability which is an objective of the statute, for such an agreement identifies the employees' recognized bargaining representative, settles questions pertaining to wages, hours, and working conditions, and betokens the successful operation of the collective bargaining process."

Container Corp. of America, 61 N.L.R.B. 823, 826 (1945) (dictum). The Supreme Court and Congress also held the view that the signing of a written contract was the final step in the bargaining process. See H. J. Heinz Co. v. NLRB, 311 U.S. 514, 524-25 (1941)

(dictum); H.R. REP. No. 1147, 74th Cong., 1st Sess. 20 (1935).

However, judicial enforcement of collective agreements is not, and never was, free irom difficulty. The view that such contracts were unenforceable, while orthodox once, generally gave way soon after the adoption of the National Labor Relations Act. 1 Teller, Labor Disputes and Collective Bargaining $\$ 163$ (1940). But traditional reluctance to consider unincorporated associations jurisitic entities often places insuperable procedural barriers to suits by or against unions. See Association of Westinghouse Salaried Employees v. Westinghouse Elec. Corp., 348 U.S. 437, 443-49 (1955). Taft-Hartley sought to resolve the paradox of rights without remedies by providing a forum in which collective contracts could be enforced. 61 STAT. 156 (1947), 29 U.S.C. $\S 185$ (1952). But recently the Court cast doubt upon the constitutionality of this provision. Association of Westinghouse Salaried Employees v. Westinghouse Elec. Corp., supra at 449-59.

44. Cf. Superior Elec. Products Corp., 6 N.L.R.B. 19, 22 (1938).

45. "But when the agreement is signed, the parties have just married and must still go through life together. While a good collective agreement is perhaps more promising of a happy future than a good marriage contract, in either case the agreement merely launches the mutual enterprise. The success of the enterprise depends upon satisfactory adjustment of the conflicts and frictions in the day-to-day life of the parties. Their collective bargaining and their negotiations begin with the agreement and continue constantly thereafter."

Shulman, The Role of the Impartial Umpire, in BakKe \& KeRr, Unions, Management and the Public 4\$5, 486 (1948). See also Shulman, Opinions of the UMrire preface (1946) ; Shulman, Reason, Contract, and Laze in Labor Relations, 68 HARv. L. REv. 999 (1955). Consistent with his belief that efficient and harmonious industrial relations can be secured only by the honest and daily cooperation of the parties, Shulman took issue with the wisdom of Taft-Hartley's provision for suits on collective bargaining agreements. Id. at 1001-02, 1023-24. But see Cox, Rights under a Labor Agreement, 69 HARV. L. REv. 601, 604-05 (1956) (some judicial enforcement beneficial). 


\section{Schism Exception}

Like the certification year rule, the contract bar rule will not be applied if the bargaining unit has changed in character, ${ }^{4 B}$ if the contracting union is defunct, ${ }^{47}$ or if a schism produces two factions claiming adversely. ${ }^{48}$ Until 1952 the latter exception allowed easy circumvention of the rule. Employees could repudiate an unsatisfactory union by voting at a meeting of the local to disaffiliate from the international, and either to affiliate with another international or to form an independent union. ${ }^{49}$ The schism between local and international was thought to create confusion as to which union was the administrator of the contract, and it was feared that unless doubt as to the identity of the contracting union was resolved by an election the grievance machinery might be halted. ${ }^{50}$

This major escape from the contract bar rule is being narrowed. In 1952 the Board, to implement a policy against membership raiding by rival unions, ruled that no elections would be allowed if another union had any part in the

46. General Motors Corp., 111 N.L.R.B. 841 (1955) (new operation); New Jersey Natural Gas Co., 101 N.L.R.B. 251 (1952) (merger); General Elec. Co., 85 N.L.R.B. 150 (1949) (plant moved to a new location). But see The Budd Co., 107 N.L.R.B. 116 (1953) (increase in number employed and new assembly line process, but no election held); Solar Mfg. Co., 110 N.L.R.B. 1188 (1954) (machine shop employees hired after contract was executed, but no election held).

For policies underlying the changed unit exception, see note 16 supra.

47. A. O. Smith Corp., 107 N.L.R.B. 1415 (1954) ; Dick Brothers, Inc., 107 N.L.R.P. 1054 (1954).

Since most unions are affiliated with an international, which can forestall the operation of the exception merely by appointing an administrator for the contract, the defunct union exception is not of much practical significance. It has been applied to affiliater unions six times since the narrowing of the schism exception in 1952. Each case presented special circumstances. C \& D Batteries, Inc., 107 N.L.R.B. 1405 (1954) (Communist dominated union); Benjamin Air Rifle, 107 N.L.R.B. 104 (1953) (same); South Fork Foundry and Wach. Co., 104 N.L.R.B. 980 (1953) (same); Ordill Foundry \& Mfg. Co., 98 N.L.R.B. 412 (1952) (international had not appointed an administrator): Prairie Mfg. Co., 104 N.L.R.B. 829 (1953) (international had executed contract when local was defunct and without consulting employees); Thomas L. Green $\&$ Cu., 103 N.L.R.B. 1023 (1953) (international had refused to sign the contract).

48. See notes 49 and 50 infra.

49. In early cases the Board would hold an election whenever a substantial doubt existed as to which labor organization was the party to the contract, Kay and Ess Co., 48 N.L.R.B. 1387 (1943), or when substantially all the membership had repudiated the union, Gelatin Products Co., 49 N.L.R.B. 173 (1943). Later the criterion was merely whether the schism had caused such confusion that the contract could no longer promotestability. Kearney \& Trecker Corp., 95 N.L.R.B. 1125 (1951); Harrisburg Ry., 94 N.L.R.B. 1028 (1951) ; Boston Mach. Works Co., 89 N.L.R.B. 59 (1950). This extension made possible an election even where one union was clearly the signatory to the contract. But there were always limitations on the schism doctrine. The meeting at which disaffiliation was voted had to have some semblance of democracy. Lewittes \& Sons, 96 N.L.R.E. 775 (1951) (no election held, because the vote did not express the desires of the membership of the union). And the disaffiliation had to be as broad as the unit covered hy the contract. Harris Products Co., 96 N.L.R.B. 812 (1951).

50. See Boston Mach. Works Co., 89 N.L.R.B. 59, 60 (1950). 
disaffiliation movement.51 This condition substantially reduced the number of cases in which the exception was applied. ${ }^{52}$ Moreover, since 1952 the Board has found that confusion over which union was bargaining agent existed only where the disaffiliation was prompted by the expulsion of the international from its federation ${ }^{53}$ or was part of a movement by many locals to disaffiliate. ${ }^{54}$ A more forthright jettisoning of the schism exception may be near. In a recent case the Board implied that an election would be allowed only if the contracting international was unable to administer the agreement. ${ }^{55}$ The absorption of the schism exception by the defunct union exception would culminate the trend toward increasing restrictions on free choice.

\section{The Rules and Their Purpose-An Appraisal}

The restrictions on freedom of choice imposed by the certification year, election year and contract bar rules place a representative beyond the control of the represented. For the internal democratic structure of a union provides little assurance that dissatisfaction with its policies can be effectively expressed within the organization. ${ }^{56}$ The political indifference of the rank and file produces small turnouts at meetings, ${ }^{57}$ and even if all members do attend, the

51. Saginaw Furniture Shops, 97 N.L.R.B. 1488 (1952).

52. The exception has been applied twenty times since 1952. In each case the Board felt there were legitimate reasons for change. Thirteen cases involved schisms in alleged Communist-dominated unions. See, e.g., Whirlpool Corp., 111 N.L.R.B. 547 (1955); Copeland Refrigeration Corp., 111 N.L.R.B. 533 (1955) ; The Magnavox Co., 111 N.L.R.B. 379 (1955). One case involved a split-off from an alleged corrupt union. San Juan Commercial Co., 111 N.L.R.B. 599 (1955). In another case the international would not administer the agreement. American Factors, Ltd., 104 N.L.R.B. 199 (1953). Five cases involved a dispute over internal management of the textile union. See, e.g., Franklin Throwing Co., 101 N.L.R.B. 153 (1952); Wade Mfg. Co., 100 N.L.R.B. 1135 (1952).

During this period the Board refused to apply the exception thirty-one times. See, a., Muskin Mfg. Co., Lab. ReL. Rep. (37 L.R.R.M. 1155) (NLRB Dec. 7, 1955); Aleo Mff. Co., 109 N.L.R.B. 1297 (1954) ; The Weatherhead Co., 108 N.L.R.B. 717 (1954).

53. Sec, e.g., The Magnavox Co., 111 N.L.R.B. 379 (1955); General Elec. Apparatus \& Serv. Shop, 110 N.L.R.B. 1054 (1954) ; A. C. Lawrence Leather Co., 108 N.L.R.B. 546 (1954).

54. See, c.g., Bryant Finishing Co., 101 N.L.R.B. 422 (1952) ; Franklin Throwing Co., 101 N.L.R.B. 153 (1952); Wade Mfg. Co., 100 N.L.R.B. 1135 (1952).

55. Muskin Mfg. Co., Lab. Rel. ReP. (37 L.R.R.M. 1155) (NLRB Dec. 7, 1955).

56. See Hoxie, The Leaders and the Rank and File, in BAKKE \& KERR, op. cit. supra note 45 , at 184 .

Most unions are organized in accordance with democratic principles with provisions for cuntrol by majority vote. E.g., Constitution of the AFL-CIO, BNA LABor PolicY AND Practices $263: 281,283$ (1956). In addition to providing for election of officers, most union constitutions require membership ratification of contracts negotiated by the leaders. Chammerlain, Collective Bargaining 77 (1951).

57. Turnout is often small at meetings called to discuss such important matters as whether to disaffiliate. See, e.g., Saginaw Furniture Shops, Inc., 97 N.L.R.B. 1488 (1952) ( 30 present out of a membership of 220) ; Phoenix Mfg. Co., 98 N.L.R.B. 803 (1952) (45 present out of a membership of 148). See also Rey xolds, Labor Economics ani LABOR Kelations 139 (1949). 
majority of members can be considerably less than the majority of employees. ${ }^{88}$ Finally, lack of an experienced opposition slate often leaves workers with no alternative but to keep unwanted officials. ${ }^{59}$

During the period of insulation from repudiation the union "is clothed with power not unlike that of a legislature."60 Even after losing support of the majority of employees unions can bind employees to a collective bargaining agreement, ${ }^{61}$ retain practical control over the grievance procedure established by the agreement, ${ }^{62}$ receive dues withheld from the employees by the employers, ${ }^{63}$ and exercise the power to manage welfare plans, including discretion in investing the funds. ${ }^{64}$

58. Generally, all employees will be members of the union only if there is a union shop contract. These contracts are valid unless in conflict with state laws. $C f$. Railway Employees' Dep't v. Hanson, 24 U.S.L. WeEK 4251 (U.S. May 21, 1956). Forty-three per cent of collective bargaining agreements contain union shop provisions. BNA CoLLECtive Bargaining Negotiations and Contracts 87:1-2 (1955).

59. Only the International Typographical Union has a fully developed party system. Reynolds, Labor Economics and Labor Relations 151 (1949). Moreover, the rule requiring members of a labor organization to exhaust their remedies within the organization before seeking judicial relief enhances the leader's hold on the organization. See Kelly v. Incitti, LAB. Ret. REP. (38 I.R.R.M. 2107) (N.Y. Sup. Ct. May 8, 1956) (union members denied injunction preventing union from interfering with their right to be nominated for office). For criticism of the exhaustion of remedies rule, see Comment, 65 YALE L.J. 369 (1956).

60. Steele v. Louisville \& N.R.R., 323 U.S. 192, 202 (1944). The quote refers specifically to unions selected under the Railway Labor Act, 44 STAr. 577 (1926), as amended, 45 U.S.C. $\$ 151$ (1952), but the powers conferred upon unions by that act are no broader than those bestowed by the National Labor Relations Act. See Williams v. Yellow Cab Co., 200 F.2d 302, 304 (3d Cir. 1952).

61. Brooks v. NLRB, 348 U.S. 60 (1954) (by implication), 69 HARv. L. REv. 185-87 (1955).

62. Section 9 (a) of the act gives individual employees the right to present grievances. 49 STAT. 453 (1935), as amended, 29 U.S.C. $\$ 159$ (a) (1952). But this right is of little practical significance. See Summers, Union Powers and Workers' Rights, 49 MICE. L. REv. 805, 814-15 (1951).

63. Withholding-or checkoff- of dues is permitted only when an employee executes a written authorization. An authorization may be irrevocable for one year. 61 STAT. 157 (1947), 29 U.S.C. $\$ 186$ (1952). Many contracts contain provisions regarding checkoff.

"About 10 percent of contracts provide that the employee may revoke his authorization at any time. Another 25 percent provide that the authorization is to be irrevocable for one year or the term of the contract, whichever is shorter. . . Other checkoff provisions do not refer to revocability."

BNA Collective Bargatning Negotiatrons and Contracts 87:661 (1955).

64. More than forty-five per cent of contracts contain employee-benefit provisions. BNA Collective Bargaining Negotiations and Contracts $44: 1$ (1955). In some plans union and management have joint control over the administration of benefits. In other plans joint control is exercised over the trust fund as well. Under the provisions of the Taft-Hartley Act, benefits set up after 1946 may not be controlled exclusively by a union. Nevertheless, in practice a few plans are administered predominantly by unions. BNA Collective Bargaining Negotiations and Contracts $44: 251,551$ (1955). 
Allowing a representative to exercise such extensive powers during a period in which it is free from the control by the represented militates against democratic principles. At common law the possibility of an agent betraying his principal's trust was checked by a general prohibition against irrevocable agencies. ${ }^{05}$ Similarly in corporate law stockholders are given the power to remove corporate officers at any time for cause. ${ }^{66}$ In government an elaborate system of checks and balances guards against abuse. It would only be in keeping with this general abhorrence of entrenched power to demand that restrictions on employee free choice be no broader than necessary to achieve industrial stability.

The cases do not reveal whether the National Labor Relations Board subscribes, even in the abstract, to this principle of limited restrictions on employee control. True, the Board generally does say that the imposition of a bar is necessary for industrial stability. ${ }^{67}$ But support for this assertion is found in the statements in previous cases rather than in a factual analysis of the way stability actually results from the bar. ${ }^{68}$ Yet the proposition that irrevocable bargaining agencies contribute to industrial peace is not self-evident. Employees may strike even if they cannot repudiate their union;' indeed the inability to repudiate may be the cause of a strike. ${ }^{70} \mathrm{~A}$ conclusion that the rules are or are not necessary to industrial stability may be drawn only after examining the ways in which the rules can promote industrial harmony.

65. Even an agency stated to be irrevocable will not necessarily be so, since ordinarily a contract not to revoke an agency is not specifically enforceable. 1 CoRsin, Contracts $\S 167$ (1950); Mechear, Agency $\$ 264$ (4th ed. 1952). Only when agency powers are coupled with an interest will an agency be irrevocable. Hunt v. Rousmanier's Administrators, 21 U.S. (8 Wheat.) 174 (1823); Restatenent, AGeNCX §§ 138, 139 (1933). However, a bargaining agency does not consist of powers coupled with an interest. Consequently, in states without labor laws abrogating common law agency doctrines, unions may be repudiated by the employees at any time. Hill v. United Pub. Workers Union, 314 Ky. 791, 236 S.W.2d 887 (1950) ; Salzman v. United Retail Employees' Local 112, 10 Ohio Op. 6 (C.P. 1937).

66. Toledo Traction, L. \& P. Co. v. Smith, 205 Fed. 643 (N.D. Ohio 1913) ; KoppitzMelchers, Inc. v. Koppitz, 351 Mich. 582, 24 N.W.2d 220 (1946) ; Markovitz v. Markovitz, $336 \mathrm{~Pa} .145,8$ A.2d 46 (1939); Ballantine, Corporations $\$ 185$ (rev. ed. 1946); 2 Fletcher, Cyclopedia of Corporations $\$ 351$ (perm. ed. 1954).

67. See, e.g., Muskin Mfg. Co., LAB. Ret. REP. (37 L.R.R.M. 1155, 1156) (NLRB Dec. 7, 1955); General Motors Corp., 102 N.L.R.B. 1140, 1142-43 (1953); Reed Roller Eit Co., 72 N.L.R.B. 927, 929-30 (1947).

68. See, e.g., Aleo Mfg. Co., 109 N.L.R.B. 1297, 1302 (1954) ; General Motors Corp., 102 N.L.R.B. 1140, 1142-43 (1953); Dennis-Mitchell Industries, 101 N.L.R.B. 846, 848 (1952).

69. A good example is the recognition strike which followed the decision in Triboro Coach Corp. v. New York Labor Board, 286 N.Y. 314, 36 N.E.2d 315 (1941), barring repudiation of the contracting union. New York Times, Aug. 9, 1941, p. 17, col. 1.

70. The Board itself has recognized this in cases holding that a contract can bar for only a reasonable time. See The Trailer Co., 51 N.L.R.B. 1106, 1111 (1943). 


\section{Incubating the Collective Bargaining Agreement: the Certification and Election} Year Rules

The certification and election year rules can enhance industrial stability by creating conditions favorable to the execution of a satisfactory collective bargaining agreement. In the Board's view such conditions do not exist where employees may be tempted to repudiate unions at the instigation of hostile employers or rival unions. ${ }^{71}$

Union rivalry may increase the demands of employees beyond the bounds of reason. In soliciting for members the opposing union may make extravagant promises. To maintain its status as bargaining representative the certified union might have to compete, promise for promise. ${ }^{72}$ As the promises become more nearly Utopian the likelihood of agreement with the employer would become more remote.

In addition union rivalry could stall the bargaining process. It is an unfair labor practice for an employer to bargain with a union pending an election. ${ }^{73}$ Consequently, without the certification and election bar rules a union defeated at a prior election could keep the victor from the bargaining table merely by filing a petition for a new election.

Absent the rules, an employer might refuse to bargain with a union in the hope that his obstinacy would cause the employees to desert the union. ${ }^{74}$ Such tactics would undoubtedly be an unfair labor practice and the employer could be ordered to bargain with the union, ${ }^{75}$ but a refusal to bargain charge

71. Brooks v. NLRB, 348 U.S. 96, 99-100 (1954).

72. Chamberlain, Coliective Bargaining 245 (1951).

73. Midwest Piping \& Supply Co., 63 N.L.R.B. 1060 (1945) (execution of contract with majority union during pendency of election an unfair labor practice); NLRB v. National Container Corp., 211 F.2d 525, 536 (2d Cir. 1954) (same); Alaska Salmon Industry, Inc., 98 N.L.R.B. 1203 (1952) (same). But see NLRB v. Standard Stecl Spring Co., 180 F.2d 942 (6th Cir. 1950) (not an unfair labor practice to bargain with a union designated by all employees during pendency of petition for election).

An employer need not refrain from bargaining with the incumbent union unless the election petition filed by the rival union raises a valid question concerning representation. William Penn Broadcasting Co., 93 N.L.R.B. 1104 (1951) (petition seeking election for an inappropriate bargaining unit will not halt bargaining). Since the Board will hold an election only if the petitioning union can show the support of at least thirty per cent of the workers, see note 23 supra, a rival union that does not meet this requisite cannot stall the bargaining process.

74. Brooks v. NLRB, 348 U.S. 96, 100 (1954). In Stanislaus Implement and Hardware Co., 101 N.L.R.B. 394, 396 (1952), the Board found as evidence of the employer's bad faith that he had said he would stall for a year and then have a decertification election.

Although an employer's refusal to bargain would most likely foster employee-union cohesion, the opposite result might obtain if the bargaining unit had only recently-and reluctantly-been organized.

75. 49 Srar. 453 (1935), as amended, 29 U.S.C. $\$ 158$ (a) (5) (1952); Cambria Clay Products Co., 106 N.L.R.B. 267 (1953); Stanislaus Implement and Hardware Co., 101 N.L.R.B. 394 (1952). Orders requiring the employer to bargain with the union are often issued. E.g., Franks Bros. Co. v. NLRB, 321 U.S. 702 (1944). 
is difficult to prove and may be evaded by well counseled employers. ${ }^{76}$ The rules immunizing unions from repudiation provide a more certain deterrent to attempts to dishearten employees.

Nevertheless, protecting certified unions from captious union rivalry and employer hostility does not offer a justification for applying the rules under all circumstances. The rules also bar repudiation inspired by genuine dissatisfaction with the certified union; it matters not whether the repudiation movement was prompted by union-employer collusion, union corruption or a failure of the leaders to honor the constitution of the union. ${ }^{77}$ In some cases the difficulty of determining whether the actual causes of a repudiation movement are legitimate may justify applying the rule. But in other situations it may be perfectly clear that a certified union's loss of majority support cannot be traced to the capricious promises of a rival union or the dilatory tactics of a hostile employer.$^{78}$ Indeed, with the amalgamation of the American Federation of Labor and the Congress of Industrial Organizations, loss of majority support due to extravagant promises of rival unions should be a rare occasion. ${ }^{70}$ The Board has ascertained whether employee discontent with unions was caused by the obstreperous tactics of employers and the unfair charges of rival unions in deciding whether to apply the schism exception. ${ }^{80}$ Certainly there is no reason why it can not do likewise in deciding whether the rules should apply at all.

It is true that permitting an election where the certified union is collusive,

76. Since the act does not compel employers to reach agreements with employees, NLRB v. Jones and Laughlin Steel Corp., 301 U.S. 1, 45 (1937), a refusal-to-bargain charge turns wholly on the subjective question of whether an employer is acting in good faith in refusing a union's demands. See NLRB v. Montgomery Ward \& Co., 133 F.2d 676, 682-85 (9th Cir. 1943). For examples of how unyielding employers may be without violating the act, see NLRE v. United Clay Mines Corp., 219 F.2d 120 (6th Cir. 1955) (employer steadfastly insisted upon right to determine grievances unilaterally); NLRB v. National Paper Co., 216 F.2d 859, 863-65 (5th Cir. 1954) (adamant refusal to discuss wage increase).

77. In the past such conduct has been the cause of repudiation movements. See, e.g., San Juan Commercial Co., 111 N.L.R.B. 599 (1955) (alleged corruption); Whirlpool Corp., 111 N.L.R.B. 547 (1955) (Communist domination); NLRB v. Globe Automatic Sprinkler Co., 199 F.2d 64 (3d Cir. 1952) (refusal to submit contract for membership ratification in accordance with constitution); Franklin Throwing Co., 101 N.L.R.B. 153 (1952) (mismanagement).

78. See cases cited note 52 supro.

79. The AFL-CIO merger agreement contains a no-raiding provision. For its text see 35 L.R.R.M. So (1955). Before the merger sixty-five AFL unions and twenty-nine CIO unions had signed a no-raiding pact. See 34 L.R.R.M. 26 (1954).

80. In deciding whether to apply an exception to be contract bar rule the Board frequently must determine whether a rival union has engaged in unlawful participation. Roberts Brass Mfg. Co., LAB. REL. ReP. (36 L.R.R.M. 1513) (NLRB Sept. 15, 1955); Arthur C. Harvey Co., 110 N.L.R.B. 338 (1954); Dick Bros., Inc., 107 N.L.R.B. 1054 (1954). And in unfair labor practice cases there is often a determination whether a union's loss of support was caused by the employer's unfair practices. NLRB v. Geigy Co., 211 F.2d 553 (9th Cir. 1954); NLRB v. Pecheur Lozenge Co., 209 F.2d 393 (2d Cir. 1953), cort. devtied, 347 U.S. 953 (1954). 
corrupt or faithless would put the bargaining process at a standstill. ${ }^{81}$ But these are the circumstances under which it is most dangerous to have bargaining continue. For it is most unlikely that such a union could obtain an agreement that would stabilize industrial relations. Indeed, the corrupt or collusive union might sacrifice workers' interests in the agreement it obtained. ${ }^{82}$ And the Board can always protect a certified union from groundless charges of corruption by refusing to entertain a petition unless proof is substantial.

Furthermore, stability cannot justify denying an election in cases where the Board has traditionally recognized an exception to the certification year rule. $^{83}$ The Board created these exceptions to avoid impasses in labor relations. ${ }^{84}$ Yet the election year rule, by placing a blanket restriction on the holding of elections, has left the Board powerless to intervene. In doing so, the rule sterilizes rather than nurtures labor relations.

\section{Preserving the Collective Bargaining Agreement: The Contract Bar Rule}

The purpose of the contract bar rule is to maintain the integrity of a collective bargaining agreement. ${ }^{85}$ Harmony will be achieved only if the parties to the agreement observe its provisions in good faith and utilize its grievance procedure ${ }^{86}$ this peace would be jeopardized if workers could select at will a new union to represent them. The succeeding union might have gained its support by promising workers a better contract, ${ }^{87}$ and following certification this union might openly breach the old agreement or subvert it in subtler ways. Nevertheless, the restrictions on free choice imposed by the contract bar rule are broader than necessary to preserve the integrity of a collective bargaining agreement. The rule bars change motivated by dissatisfaction with a union's administration of the contract. ${ }^{s s}$ Protestations by the new union that it is willing to abide by both the letter and the spirit of the agreement are of no avail. ${ }^{80}$

81. See note 73 supra and accompanying text.

82. For case studies of sell-outs by corrupt union leaders, see Goodman, Muscling in on Labor, New Republic, April 30, 1956, p. 8; May 14, 1956, p. 13; JoHnson, CRIME oN the Labor Front passim (1950).

See 100 Cong. Rrc. 271 (1954) for description of a shut-down in the construction industry precipitated by an allegedly corrupt union.

83. See notes 13-15 supra and accompanying text.

84. See note 16 supra.

85. See Container Corp. of America, 61 N.L.R.B. 823 (1945). "[T]he practice of collective bargaining is, in general, best encouraged by leaving undisturbed the tripartite relationships defined in trade agreements." Id. at 826 .

86. Shularan, Opinions of the UMrPiRe preface (1946) ; Ford Motor Co., Arbitration Award, Opinion A-190 (May 15, 1945), in Shularas, op. cit. supra.

87. See, e.g., Barton Distilling, 106 N.L.R.B. 361 (1953) (union seeking election had promised employees a better contract). See note 72 supra.

88. See, e.g., The Weatherhead Co., 108 N.L.R.B. 717 (1954) (cause of the disaffiliation was a dispute over the handling of grievances).

89. R. C. Williams \& Co., 107 N.L.R.B. 933 (1954); The Budd Co., 107 N.L.R.B. 116, 121 (1953) ; Sun Shipbuilding \& Dry Dock Co., 86 N.L.R.B. 20 (1949) (rule applies, but requisites of schism exception met). 
And elections have been denied where the employer states that he will accept the new union as substitute for the contracting party. ${ }^{80}$

\section{ReCOMIMENDATIONS AND CONCLUSTON}

In summary, the three rules unduly restrict a worker's freedom of choice. The certification year and election year rules, intended to promote stability by discouraging union rivalry and employer hostility, bar change in situations where these disruptive forces are absent. The election year rule does not admit of even the limited exceptions to which the certification year rule is subject. Finally, the contract bar rule, designed to preserve the integrity of contracts, bars change even though the new union is willing to adopt the agreement.

Purposeless restrictions on the right to repudiate should not be tolerated. Accordingly, the certification and election year rule should be amended to permit repudiation of a union where the party seeking the new election can show that the repudiation movement was not inspired by employer hostility or unfair methods of union rivalry. ${ }^{01}$ This burden should be considered met when there is convincing proof of corruption, collusion with the employer or faithlessness to the union's constitution. The election year rule as well should be made subject to the defunct union exception. Finally, the contract bar rule should not be applied where the employer is willing to accept the new union as party to the agreement, or the Board is convinced that the new union will abide by the agreement. To insure adherence to the contract, the election could be expressly limited to determining which union should administer the contract, a procedure used by the NLRB in the early days of the Wagner Act. ${ }^{92}$

90. In many schism cases the employer is neutral on the issue of whether the contract should bar. See, e.g., Dick Bros., Inc., 107 N.I.R.B. 1054 (1954); Pepsi-Cola Buffalo Bottling Corp., 107 N.L.R.B. 990 (1954); R. C. Williams \& Co., 107 N.L.R.B. 933 (1954).

91. There is precedent for such rules in state labor relations acts. Both the Wisconsin and Minnesota statutes provide that an election can be held during the certification year if good cause exists. Mrnn. Stat. AnN. \$ 179.16(2) (Supp. 1955); Wrs. Stat. $\S 111.05$ (1953).

92. The Register and Tribune Co., 60 N.L.R.B. 360 (1945); Barbison-Walker Refractories Co., 43 N.L.R.B. 1349 (1942). See also New England Transp. Co., 1 N.L.R.B. 130 (1936) (practice before adoption of contract bar rule). The Board expressly repudiated this practice in 1950 on the theory that it was not its function to suggest the legal consequences of certification. Boston Mach. Works Co., 89 N.L.R.B. 59 (1950). As a result directions for elections during the life of a contract no longer contain limitations. Ibid.

An amendment requiring the Board to condition its certifications on the acceptance of the terms of an outstanding contract was rejected in conference by the House. H.R. REP. No. 510, 80th Cong., 1st Sess. 50 (1947). Drawing a negative inference from this, the Board has ruled that is is powerless to issue conditional certifications. Boston Mach. Works Co., supra. But the Board's interpretation of congressional intent from failure to pass the amendment is not persuasive. The committee indicated that the amendment was withdrawn solely to avoid creating the impression "that the practice of the Board with respect to conducting representation elections while collective bargaining contracts are in effect should not be continued." H.R. REP. No. 510, supra. 


\section{Authority of the Board to Make the Changes}

The Board does not have full authority to make these changes. Only Congress can amend the election year rule. And the courts have the final say whether a union may succeed to the contractual rights and duties of its predecessor. Pending amendment of the election year rule, however, the Board may grant employees relief from the powers of unwanted unions. The Board could revoke the certification of unions which have lost majority support for reasons not associated with union rivalry or employer hostility. Revocation has been used on occasion and appears to be within the power of the Board.93 Once the certification of a union is revoked, the employees would be free to bargain individually or collectively with the employer. ${ }^{94}$ But they would still not be able to elect a new union during the election year. ${ }^{95}$

The Board's ability to liberalize the contract bar rule is entirely dependent upon the cooperation of the courts, for actions on contracts are within the jurisdiction of the courts, not the Board.96 The reaction of courts to a Board certification conditioned upon acceptance of a contract may be assayed from state cases dealing with change of union during the life of an agreement. There a formidable body of contract doctrine holds that the signatory union remains entitled to the rights and bound by the obligations of the contract. ${ }^{07}$ Thus even after a new union has been selected, courts have allowed the contracting union to administer trust funds, ${ }^{98}$ maintain a closed shop, ${ }^{99}$ and receive union dues withheld by the employer. ${ }^{100}$ Conversely, new unions have been denied the right to enforce the collective bargaining agreement. ${ }^{101}$

These cases rest on narrow notions of privity. The signatory union is considered the real party to the contract. ${ }^{102}$ Therefore unless the contracting union consents, a new union cannot be substituted in its place. ${ }^{103}$ But even assuming that the requisite of privity must be met to enforce a collective bargaining agree-

93. Hughes Tool Co., 104 N.L.R.B. 318 (1953), 54 Colum. L. Rev. 135 (1954), 67 HaRv. L. Rev. 522 (1954) (certification revoked conditionally for union's discrimination against non-members).

94. Upon revocation individual bargaining would prevail. If the employees should thereafter informally designate a new union by clear majority, the employer would be under a duty to bargain, since that duty is not conditioned upon an election and certification. NLRB v. Kobritz, 193 F.2d 8 (1st Cir. 1951).

95. See note 17 supra.

96. Boston Mach. Works Co., 89 N.L.R.B. 59 (1950).

97. See Comment, 51 YALE L.J. 465, 472-75 (1942).

98. Suffridge v. O'Grady, 84 N.Y.S.2d 211 (Sup. Ct. 1948).

99. Pennsylvania Labor Relations Board v. Red Star Shoe Repairing Co., 2 L.R.R.M. 882 (Pa. C.P. 1938).

100. Local 60, Industrial Union of Marine Workers, ClO v. Welin Davit and Boat Corp., 133 N.J. Eq. 551, 33 A.2d 708 (Ch. 1943).

101. Morrison v. Majestic Laundry System, Inc., 103 N.Y.S.2d 791, 799 (Sup. Ct. 1951).

102. See also Comment, 51 YaLe L.J. 465, $472-75$ (1942).

103. A novation requires consent of the original parties. Restatement, Contracts $\$ \S 424,429$ (1932). 
ment, this conclusion need not follow. The members of the bargaining unit, rather than the contracting union, could be considered party to the contract. ${ }^{104}$ So viewed, the status of the contracting representative would be assimilated to that of an agent, and each succeeding union would be allowed to enforce the rights and forced to carry out the duties of the employees under the agreement. However, a more realistic approach would be to consider collective bargaining agreements sui generis and allow substitution, not because contract doctrine can be strained to permit it, but because a well-balanced labor policy demands it. ${ }^{105}$

Restrictive state court decisions need not defeat the Board's efforts to substitute new parties to contracts. For the effect of a Board certification on an

104. In A. R. Barnes \& Co. v. Berry, 169 Fed. 225, 228-29 (6th Cir. 1909), appellants' theory that a collective agreement between an employers' association and a union was in reality an agreement between each employer and his employees was used to sustain diversity jurisdiction. For brief discussion of use of the theory to sustain substitution, see Comment, 51 YaLe L.J. 465, 471-72 (1942) ; Larson, The Labor Relations Acts-Their Effect on Industrial Welfare, $36 \mathrm{MrcH}$. L. Rev. 1237, 1254 (1938). For criticism of this theory, see Wilcox, The Triboro Case-Monntain or Molehill?, 56 Harv. L. Rev. 576, 59 (1943) ; Rice, Collective Labor Agrecments in American Law, 44 HaRv. L. Rev. 572, 593-95 (1931).

While Barmes is the only case viewing a collective agreement as a contract between the workers and employer. several courts have held that the individualized rights under collective agreements belong to the workers rather than to the union. See Association of Westinghouse Salaried Employees v. Westinghouse Elec. Corp., 210 F.2d 623 (3d Cir. 1954) (union improper party to maintain suit for vacation pay, but if occasion arose could enforce, inter alia, lockout, union shop and arbitration provisions), aff'd, 348 U.S. 437 (1955) (but theory expressly rejected by majority of Court) ; Federation of Westinghouse Independent Salaried Unions v. Westinghouse Corp., LAB. ReL. REP. (38 L.R.R.M. 2234) (Pa. C.P. Feb. 17, 1956) (employees and union may join in spurious class suit for overtime pay, the workers being entitled to actual damages, and the union, nominal damages). Under a compartmentalized view of collective bargaining agreements, substitution of a new union to a contract is of significance only with respect to those provisions enforceable by or against the union.

105. "The principles determining legal rights and duties under a collective bargaining agreement should not be imposed from above; they should be drawn out of the institutions of labor relations and shaped to their needs." Cox, Rights under a Labor Agreement, 69 H.Ak: L. Rev. 601, 605 (1956). Several other distinguished scholars have suggested treating collective contracts sui gencris. See Shulman, Reason, Contract and Law in Labor Rilations, 68 Hanv. L. Rev. 999 (1955); Witmer, Collective Labor Agreements in the (outrs, 48 YALE L.J. 195 (1938).

Substitution will be facilitated if the agreement provides that it will bind the union's unceessors. See Agreement between Bendix Aziation Corp., Scintilla Magneto Div., and Machinists-A.F.L., BNA, Collective Bargaining Negotiations and Contracts 70:181-82 (1955). Although orthodox contract doctrine does not allow a contracting union to impose duties upon a union ousting it as representative of the workers, one court has given effect to such a provision. Louisville Ry. v. Louisville Area Transp. Workers Union, 312 Ky. 657, 22S S.W.2d 652 (1950). Another has suggested it. Modine Mfg. Co. v. Grand Ludge Int'1 Ass'n of Machinists, 216 F.2d 326 (6th Cir. 1954). If, on the other hand, a contract expressly states that it will cease to be binding if another union is certified, the contract does not bar an election. Willys Overland Motors, Inc., 35 N.L.R.B. 549 (1941). 
existing contract is a federal question, the answer to which lies in the policy of the act, and not in the contract rules of the forum. ${ }^{106}$ And the Board has been given a preferred, though not conclusive, role in interpreting the policy of the act. ${ }^{107}$

\section{Conclusion}

Employees can be granted greater freedom to switch bargaining representatives without increasing industrial unrest. This Comment has suggested three changes in the bar rules that will maximize employee freedom of choice and industrial peace. It may be, however, that the period has passed in which employer hostility and union rivalry are sufficient threats to industrial harmony to require any abridgment of workers' rights to bargaining representation of their own choosing. This is a question of fact that should be reappraised periodically. Labor relations is too dynamic a subject for the Board or Congress to rely solely on precedent.

106. Modine Mfg. Co. v. Grand Lodge Int'l Ass'n of Machinists, supra note 105. But see John Hancock Mut. Life Ins. Co. v. United Office \& Professional Workers, 93 F. Supp. 296 (D.N.J. 1950) (contractual rights of union ousted without NLRB election governed by state law). Mforeover, several courts have held that $\$ 301$ of Taft-Hartley, 61 STAT. 156,29 U.S.C. $\$ 185$ (1952), makes federal law determinative of all questions arising out of collective bargaining contracts in interstate commerce. See, e.g., Local \$66, United Automobile Workers, CIO v. Buffalo-Springfield Roller Co., 131 F. Supp. 667, 668 (S.D. Ohio 1954) ; International Plainfield Motor Co. v. Local 343, United Automobile Workers, CIO, 123 F. Supp. 683, 692 (D.N.J. 1954). But see Association of Westinghouse Salaried Employees v. Westinghouse Elec. Corp., 348 U.S. 437, $452-58$ (1955) (Frankfurter, J.; dictum).

107. See, e.g., Local 420, United Ass'n of Journeymen and Apprentices of the Plumbing Industry v. Carrier Corp., 130 F. Supp. 26 (E.D. Pa. 1955) (finding that a contract clause was illegal was based on Board's interpretation of the act). 